\title{
The approximated dynamic vehicle characteristics constructed based on the driving tests
}

\begin{abstract}
The paper presents the issue of the construction of the fuel consumption and exhaust emissions dynamic characteristics based on the data obtained during the NEDC and FTP-75 driving tests. The results presented in the publication are based on the tests of a class $C$ vehicle, performed in a certified exhaust emissions laboratory. The distributions of engine crankshaft accelerations as a function of its speed for both tests at 1-second intervals have been collated. At these points the measurements of the exhaust emissions were carried out. The authors described the conditions in which modal measurements of the fuel consumption and exhaust emissions in both tests were carried out. The results of the measurements were used for the construction of the approximated characteristics being the functions of velocity and acceleration of the engine crankshaft. Based on the obtained measuring results the approximated dynamic characteristics of the emissions of the four main exhaust components have been developed and the approximations were done with the use of the third order functions. An analysis of the obtained results has been performed and the authors presented the differences resulting from the construction of the above characteristics based on the combined data from the NEDC and FTP-75 tests and each of the tests separately. Moreover, the differences between the data obtained from the individual tests have been presented and evaluated graphically. The obtained results have been summarized and evaluated.
\end{abstract}

Key words: exhaust emissions, environment, dynamic exhaust emissions characteristics

\section{Aproksymowane charakterystyki dynamiczne pojazdów budowane na postawie testów jezdnych}

W publikacji przedstawiono zagadnienie budowy charakterystyk dynamicznych zużycia paliwa i emisji składników spalin, opierając się na danych pomiarowych uzyskanych z testów jezdnych NEDC i FTP -75. W artykule zaprezentowano wyniki badań konkretnego samochodu klasy $C$, przeprowadzonych w certyfikowanym laboratorium pomiarów toksyczności spalin. Zestawiono rozkład przyspieszeń wału korbowego silnika w zależności od jego prędkości kątowych dla obydwu testów w kroku, co jedna sekundę. W tych punktach prowadzono badania emisji drogowej składników spalin. Opisano warunki prowadzenia modalnych pomiarów zużycia paliwa i emisji składników spalin w obydwu testach. Wyniki pomiarów wykorzystano do budowy aproksymowanych charakterystyk będących funkcjami prędkości i przyspieszeń watu korbowego silnika. Na podstawie uzyskanych wyników opracowano aproksymowane charakterystyki dynamiczne emisji czterech podstawowych składników spalin przy aproksymacji funkcjami trzeciego stopnia. Przeprowadzono analizę uzyskanych wyników i zaprezentowano różnice wynikające z tworzenia wspomnianych charakterystyk na bazie połaczonych danych z testów NEDC i FTP-75 i przy budowie tych charakterystyk na podstawie każdego z tych testów oddzielnie. Oceniono i zaprezentowano graficznie różnice danych uzyskiwanych z poszczególnych testów. Podsumowano i oceniono uzyskane wyniki.

Słowa kluczowe: emisja spalin, ochrona środowiska, charakterystyki dynamiczne emisji

\section{Introduction}

In the calculations of the fuel consumption or exhaust emissions universal characteristics are frequently used on which the points or lines are overlain of moments of motion resistance depending on the individual vehicle features or traffic conditions. Such actions allow an obtainment of positive results at relatively low accelerations [1]. At more dynamic traffic conditions the dynamic characteristics, whose build has been described in this paper, may turn out useful. The methodology of obtaining of the presented dynamic characteristics is based on the modal measurements of the exhaust emissions in typical driving tests-NEDC and FTP-75. The fuel consumption is calculated from the mass of carbon in the exhaust [2], which allows developing of the dynamic characteristics of fuel consumption.

Most of the exhaust gas components are emitted as a result of a cold start [3]. The latest trends in the legislative di-

\section{Wstęp}

W obliczeniach zużycia paliwa lub emisji składników spalin często wykorzystuje się charakterystyki uniwersalne silnika, na które nanoszone są punkty lub linie momentów oporu ruchu, zależne od cech pojazdu i warunków ruchu. Takie postępowanie pozwala na uzyskiwanie poprawnych wyników przy stosunkowo niewielkich przyspieszeniach [1]. W bardziej dynamicznych warunkach ruchu przydatne mogą być charakterystyki dynamiczne, których budowę opisano w niniejszym artykule. Metodyka uzyskiwania prezentowanych charakterystyk dynamicznych oparta jest na modalnych pomiarach emisji składników spalin w typowych testach jezdnych NEDC i FTP-75. Zużycie paliwa obliczano z masy węgla w spalinach [2], co pozwalało na opracowanie charakterystyk dynamicznych zużycia paliwa.

Większość składników spalin jest emitowana po tzw. zimnym rozruchu [3]. Najnowsze trendy w dyrektywach 
rectives [8] provide for a reduction of the engine temperature at start-up and a reduction in the time from the engine start to the initiation of driving, which will increase the exhaust emissions even more.

Putting stress on the cold start emissions aims at forcing the manufacturers to better protect the urbanized areas against pollution.

Under real traffic conditions the engine operating states in non-steady thermal conditions are a fraction of the total vehicle operating time. From this we can conclude that the on-road emissions $(\mathrm{g} / \mathrm{km})$ obtained in the driving tests NEDC and FTP-75 imperfectly reflect the impact of the automotive-generated pollutants on the environment while analyzing traffic of higher average cruising speeds, at a nominal temperature of the catalyst operation.

In this paper the authors propose for the analysis of such traffic conditions a use of the data collected from the driving tests NEDC and FTP-75 excluding the cold start phases. The test areas adopted for further analyses have been indicated in Fig. 1 and 2. At an interval of 1 second it gives approximately 1400 measuring points for the FTP-75 and 1000 points for the NEDC tests.

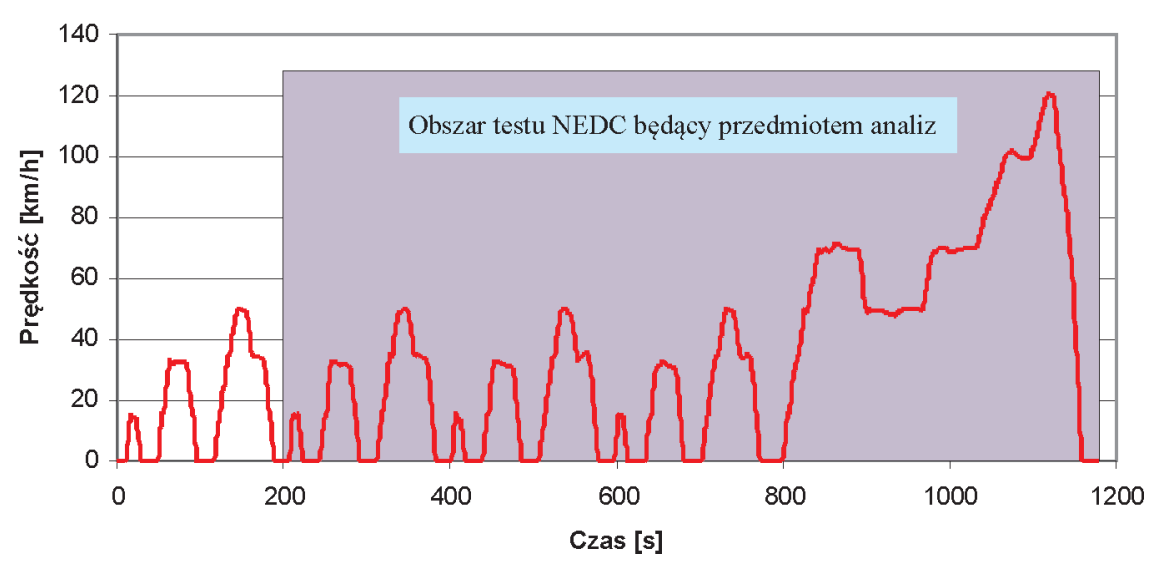

Fig. 1. NEDC driving test with the marked ranges that were subjected to the analysis Rys. 1. Test jezdny NEDC z zaznaczonymi zakresami, które byly przedmiotem analiz legislacyjnych [8] przewidują obniżenie temperatury silnika w momencie rozruchu i skrócenie czasu od rozruchu silnika do początku jazdy, co w jeszcze większym stopniu zwiększy emisję.

Położenie nacisku na emisję po zimnym rozruchu ma zmusić producentów samochodów do lepszej ochrony przed skażeniami obszarów zurbanizowanych.

W rzeczywistych warunkach ruchu stany pracy silnika w nieustalonych warunkach cieplnych stanowią bardzo niewielki ułamek całkowitego czasu ruchu pojazdu. Można z tego wyciągnąć wniosek, że wyniki emisji drogowej $(\mathrm{g} / \mathrm{km})$ uzyskane w testach jezdnych NEDC i FTP-75 niewłaściwie odwzorowują oddziaływanie skażeń pochodzenia motoryzacyjnego na środowisko przy analizie ruchu na trasach o większych średnich prędkościach przejazdu, przy nominalnej temperaturze pracy katalizatorów.

W niniejszym opracowaniu proponuje się przyjąć do analiz takich warunków ruchu dane zebrane z emisji składników spalin w testach jezdnych NEDC i FTP-75, z wyłączeniem tzw. faz zimnych. Obszary testów przyjmowane do dalszych analiz oznaczono na rys. 1 i 2 . Przy kroku 1 sek. daje to ok. 1400 punktów pomiarowych dla testu FTP-75 i 1000 dla testu NEDC.

Jeżeli przyjmie się emisję drogową jako funkcję prędkości i przyspieszenia (lub prędkości kątowej wału silnika i jego przyspieszenia kątowego), to zbiór punktów pomiarowych w tych współrzędnych można przedstawić jak na rys. 3 i 4 .

Zbiór ten jest obrazem połączonych punktów pomiarowych przy realizacji testów NEDC i FTP-75 przy kroku 1 sekundy. Oczywiście, przy przedstawionym podejściu do charakterystyk emisyjności na rysunkach tych nie ujęto punktów wyłączonych z oceny (dotyczących zimnego rozruchu).
If we assume the on-road emissions as a function of speed and acceleration (or angular velocity of the crankshaft and its angular acceleration) then the set of the measuring points in these coordinates can be presented as in Fig. 3 and 4.

This set is an image of connected measuring points when realizing the NEDC and FTP-75 driving tests at the interval of 1 second. Obviously, at the presented approach to the emissions characteristics these figures do not show the points excluded from the evaluations (those related to the cold start).

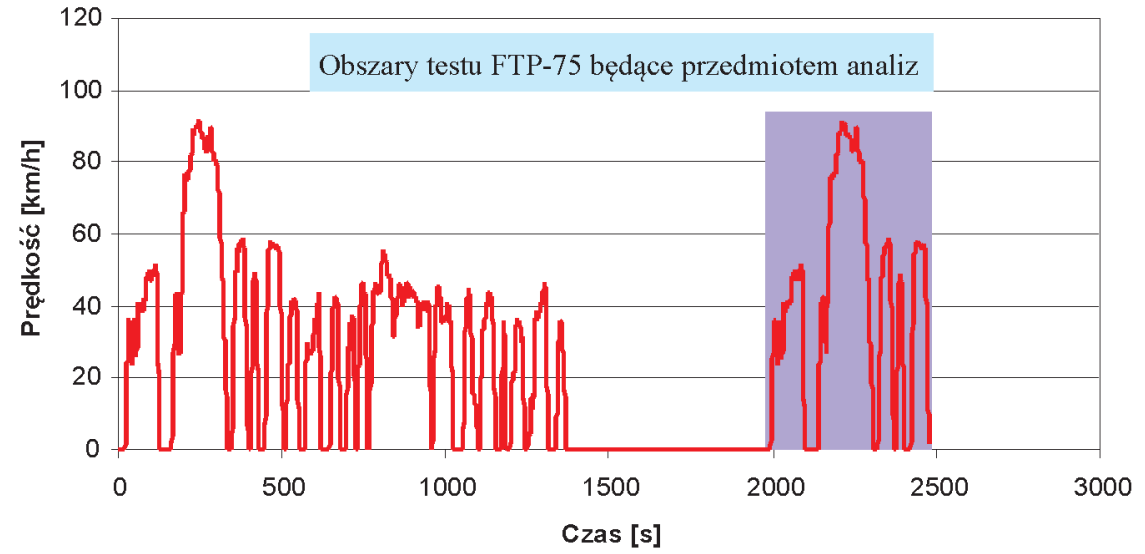

Fig. 2. FTP-75 driving test with the marked ranges that were subjected to the analysis Rys. 2. Test jezdny FTP-75 z zaznaczonymi zakresami, które byly przedmiotem analiz 


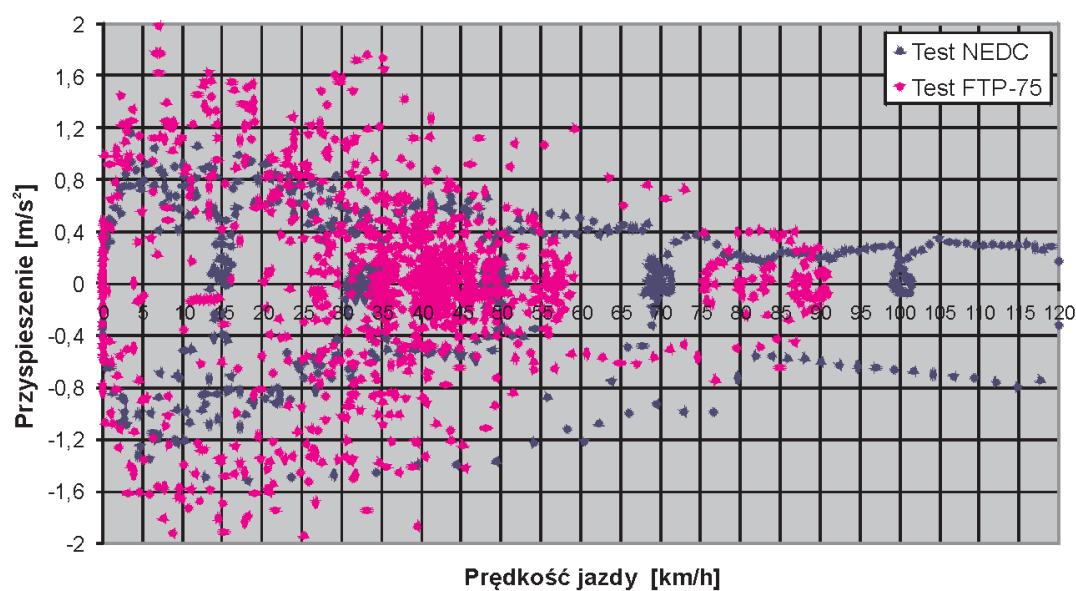

Fig. 3. The set of locations of the measuring points in the NEDC and FTP-75 driving tests in the coordinates of acceleration and driving speed, cold phases excluded

Rys. 3. Zbiór rozmieszczenia punktów pomiarowych $w$ testach jezdnych NEDC i FTP-75 we wspótrzędnych przyspieszenie i prędkość jazdy przy pominięciu faz zimnych

As results form Fig. 4 much measurement data falls in the acceleration range $\pm 10 \mathrm{rad} / \mathrm{s}^{2}$ and speeds $160-325 \mathrm{rad} / \mathrm{s}$. The measurement data from this range can constitute a basis for the construction of dynamic characteristics that provide the relation of the fuel consumption or onroad emission and the accelerations and speeds. We can accept the most accurate mapping of the characteristics in this very range. The conducted works based on the real vehicle testing has shown errors at decelerations (engine braking). Attention has been devoted to this issue in [9] having tested the emissions during engine braking on a chassis dynamometer. We need to remember though that the characteristics obtained in such a way refer to a given engine and vehicle type. The idea of the creation of these characteristics is based on the multinomial approximation (having excluded the data from cold starts). The issues of approximation when creating dynamic characteristics have been devoted attention in several publications $[5,6,7]$. In paper [4] a proposal of conjoining of the construction of the dynamic emissions characteristics with the dynamic characteristics of a given vehicle has been put forward. In this paper the approximation was performed with the use of SURFER ver. 8 where the approximating multinomial approximates a given function $\mathrm{f}(\mathrm{x})$ with the least squares method.

\section{Measurement data}

The emission tests were performed in a certified exhaust emission laboratory (certified for Euro 5). The object of the research was a passenger car of segment $\mathrm{C}$ of technical specifications given in the Table 1 .

During the realization of the FTP-75 test the gearshifts were done according to the adopted plan presented in Fig. 5 and 6.
Jak wynika z rys. 4 duża liczba danych pomiarowych mieści się w obszarze przyspieszeń $\pm 10 \mathrm{rad} / \mathrm{s}^{2}$ i prędkościach $160-325 \mathrm{rad} / \mathrm{s}$. Dane pomiarowe $\mathrm{z}$ tego obszaru mogą stanowić bazę do budowy charakterystyk dynamicznych podających zależność zużycia paliwa lub emisji drogowej składników spalin od przyspieszeń i prędkości. Można się przy tym spodziewać uzyskiwania największych dokładności odwzorowań charakterystyk dynamicznych właśnie w tym obszarze. Przeprowadzone prace oparte na badaniach rzeczywistego samochodu wykazały jednak znaczne błędy przy przyspieszeniach ujemnych (hamowanie silnikiem). Temu problemowi poświęcono opracowanie [9] po przebadaniu emisji składników spalin w trakcie hamowania silnikiem na hamowni podwoziowej.

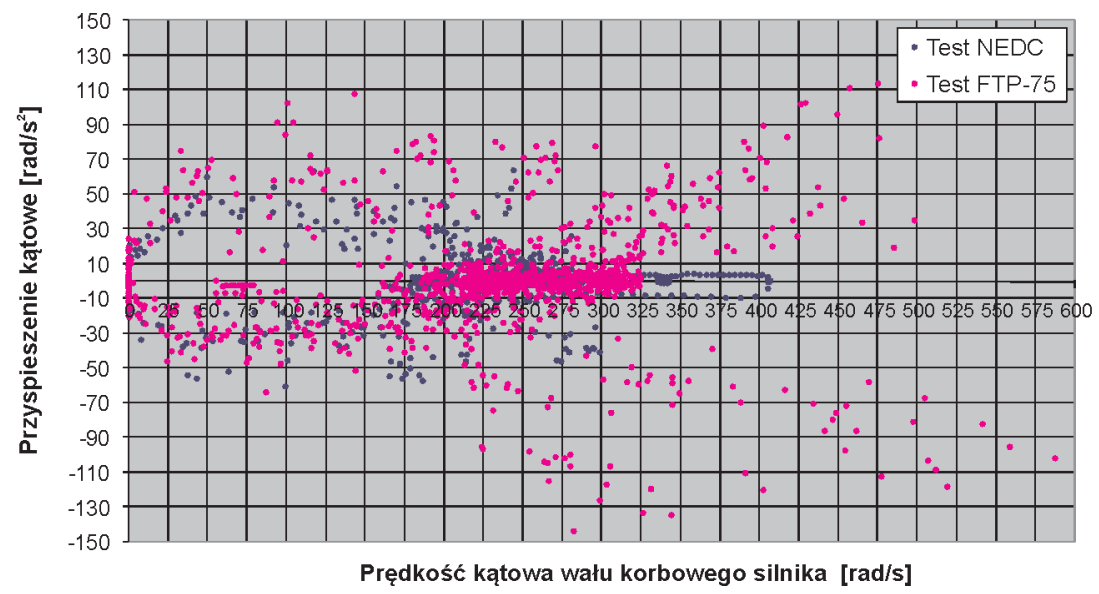

Fig. 4. The set of locations of the measuring points in the NEDC and FTP-75 driving tests in the dinates of angular velocity and angular acceleration of the crankshaft, cold phases excluded

Rys. 4. Zbiór rozmieszczenia punktów pomiarowych $w$ testach jezdnych NEDC i FTP-75 we wspótrzędnych prędkość kątowa i przyspieszenie kątowe watu korbowego silnika przy pominięciu faz zimnych

Należy przy tym pamiętać, że tak uzyskane charakterystyki odnoszą się do danego typu silnika i określonego typu pojazdu. Ideę tworzenia tych charakterystyk oparto na metodzie aproksymacji wielomianami (po wyłączeniu danych z zimnych rozruchów). Zagadnieniom aproksymacji przy tworzeniu dynamicznych charakterystyk emisyjności poświęcono kilka publikacji [5, 6, 7]. W opracowaniu [4] przedstawiono propozycję powiązania budowy charakterystyk dynamicznych emisyjności z charakterystyką dynamiczną danego typu pojazdu. W niniejszym opracowaniu przeprowadzono aproksymacje przy użyciu programu SURFER ver. 8, w którym wielomian aproksymujący przybliża daną funkcję $\mathrm{f}(\mathrm{x})$ metodą najmniejszych kwadratów.

\section{Dane pomiarowe}

Badania emisji składników spalin prowadzono w certyfikowanym laboratorium toksyczności spalin przystosowanym 
Table 1. Vehicle data

Tabela 1. Dane samochodu

\begin{tabular}{|l|l|c|}
\hline 1. & Year of manufacture/rok produkcji & 2005 \\
\hline 2. & Engine displacement/objętość skokowa silnika $\left[\mathrm{cm}^{3}\right]$ & 1596 \\
\hline 3. & Fuel feed/rodzaj zasilania benzyna & Sequential multipoint injection/wtrysk wielopunktowy, sekwencyjny \\
\hline 4. & Transmission/skrzynia biegów & 5-speed manual/mechaniczna, 5-biegowa \\
\hline 5. & Gross vehicle weight/dopuszczalna masa calkowita $[\mathrm{kg}]$ & 2300 \\
\hline 6. & Tires/ogumienie & Bridgestone B391 175/70R14 \\
\hline 7. & Tire pressure/ciśnienie w ogumieniu $[\mathrm{MPa}]$ & Front 0.26/rear 0.30 \\
\hline 8. & Maximum power output/moc maksymalna silnika $[\mathrm{kW}]$ & $76 / 5750 \mathrm{rpm}$ \\
\hline 9. & Maximum torque/maksymalny moment obrotowy $[\mathrm{N} \cdot \mathrm{m}]$ & $145 / 4000 \mathrm{rpm}$ \\
\hline 10. & Curb weight/masa własna $[\mathrm{kg}]$ & 1540 \\
\hline 11. & $\begin{array}{l}\text { Curb weight plus 2 persons and the measurement equipment } / \text { masa } \\
\text { własna }+2 \text { osoby }+ \text { aparatura pomiarowa }[\mathrm{kg}]\end{array}$ & 1750 \\
\hline 12. & Vehicle mileage/przebieg samochodu $[\mathrm{km}]$ & 65400 \\
\hline
\end{tabular}

\section{The results of the approximation and comparison}

The results of the on-road emission tests obtained during the realization of the NEDC and FTP-75 driving tests served for the construction of the approximated dynamic characteristics of the emission of four basic exhaust gas components i.e. carbon dioxide, carbon monoxide, hydrocarbons and nitric oxides. The approximation was performed with multinomial functions of the third order separately for each test and for the combined data from all tests. As a reference basis the authors took the approximated characteristics obtained from the combined data from NEDC+FTP-75. With this characteristics the values obtained from the approximated characteristics were compared using the data from individual tests. The differences have been presented in Fig. 7-10.

It is noteworthy that the approximation errors based on the NEDC test results are significant and have negative values as compared to the errors of approximation based on the combined data from the NEDC and

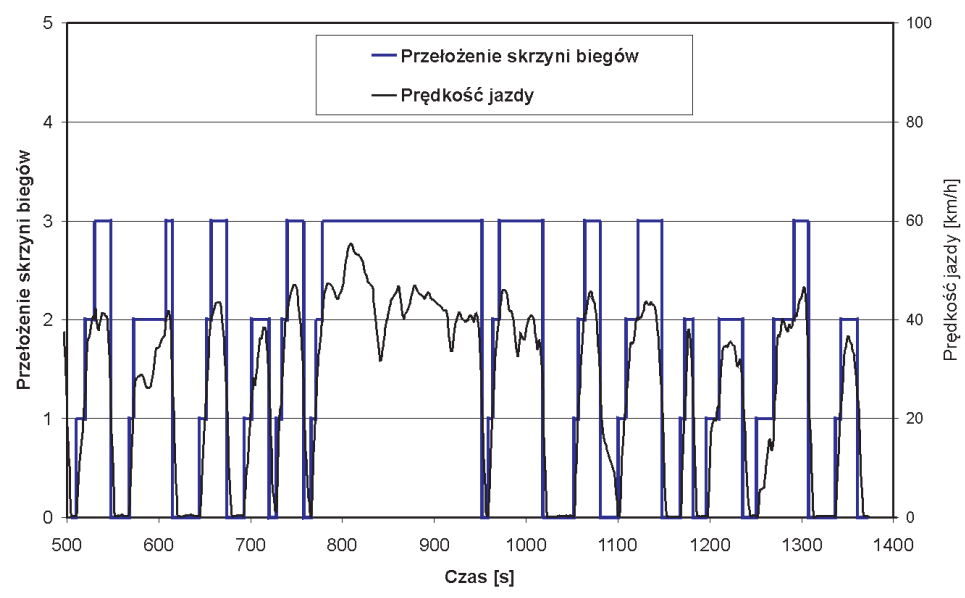

Fig. 6. Driving speed for the steady phase of the U.S. driving test FTP-75 with marked manual gearbox ratios

Rys. 6. Prędkość jazdy dla ustabilizowanej fazy amerykańskiego testu jezdnego FTP-75 z zaznaczonymi przełożeniami manualnej skrzyni biegów

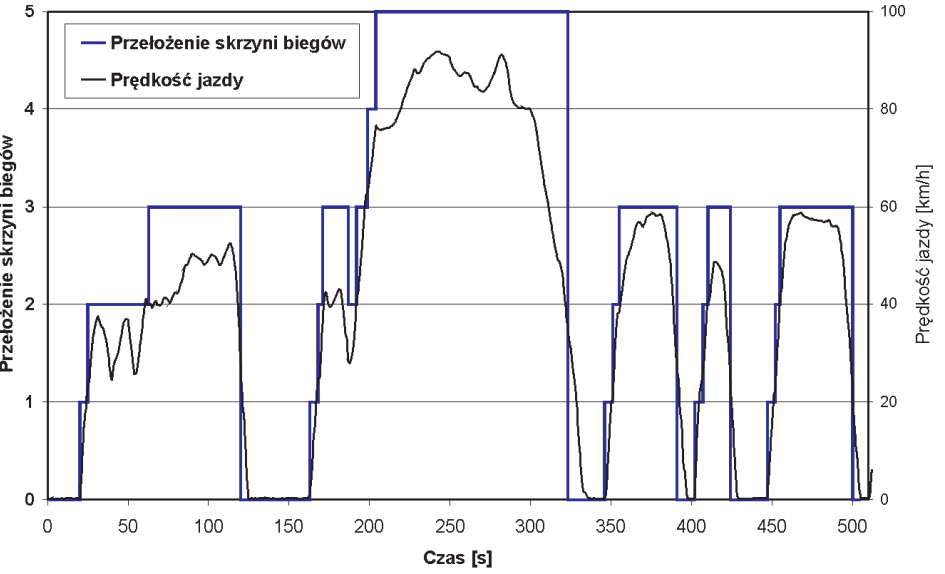

Fig. 5. Driving speed and manual gearbox ratios in the implementation of the transitional phases of the FTP-75 driving test

Rys. 5. Prędkość jazdy i przełożenia manualnej skrzyni biegów przy realizacji faz przejściowych testu FTP-75

do pomiarów na poziomie wymagań Euro 5. Obiektem badań był samochód osobowy klasy handlowej $\mathrm{C}$, o danych zestawionych w tablicy 1 .

Podczas realizacji testu FTP-75 przełączenia biegów następowały zgodnie z przyjętym grafikiem zaprezentowanym na rys. 5 i 6.

\section{Wyniki aproksymacji i ich porównanie}

Wyniki badań emisji drogowej uzyskane podczas realizacji testów jezdnych NEDC i FTP-75 posłużyły do budowy aproksymowanych charakterystyk dynamicznych emisji czterech podstawowych składników spalin, tj. dwutlenku węgla, tlenku węgla, węglowodorów i tlenków azotu. Przeprowadzono aproksymację funkcjami wielomianowymi trzeciego stopnia, oddzielnie dla danych z każdego testu oraz dla połączonych danych $z$ tych testów. Za bazę odniesienia przyjęto aproksymowane charakterystyki uzyskane z połączonych danych NEDC+FTP-75. Do tej charakterystyki odnoszono wartości uzyskiwane z aproksymowanych charakterystyk przy wyko- 
Zasilanie benzyną - III stopieñ

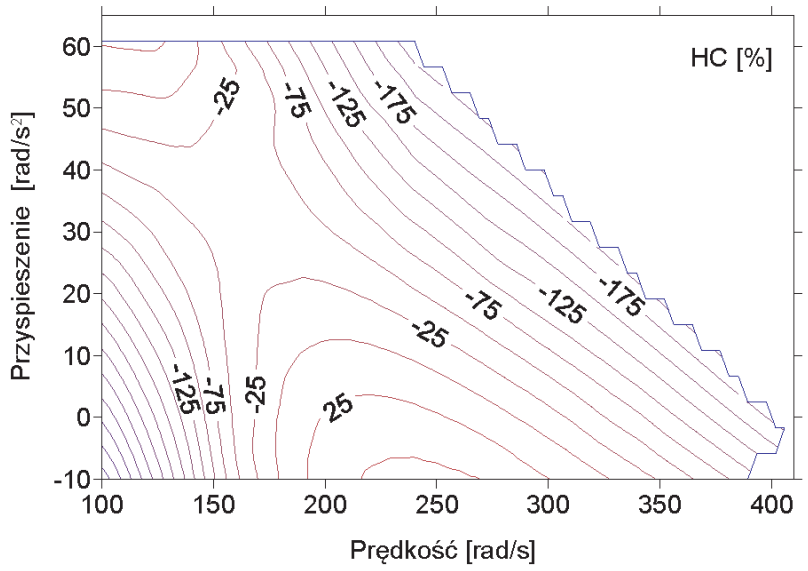

Zasilanie benzyną - III stopieñ

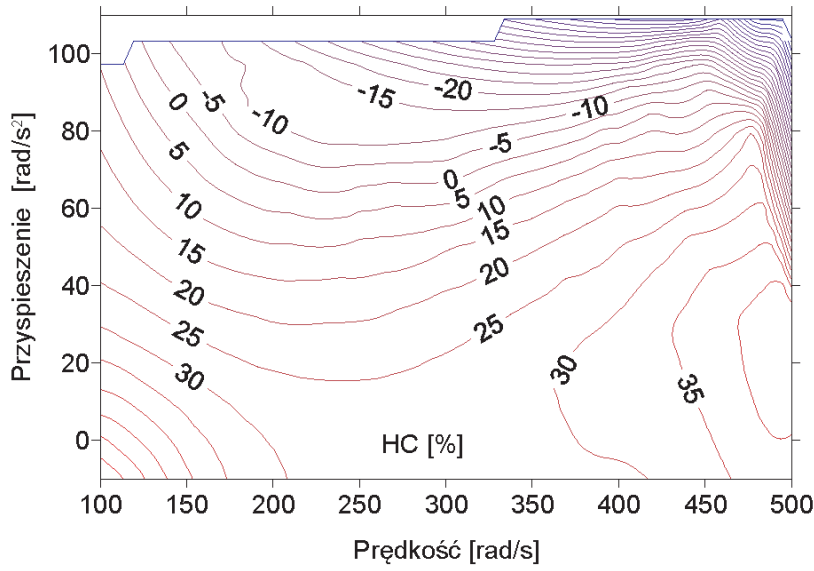

Fig. 7. Errors between the approximation based on the combined data from the FTP-75 and the NEDC and the approximation based on the measurements of only the NEDC and only the FTP-75 for the road emissions of hydrocarbons for gasoline fuelling

Rys. 7. Błędy między aproksymacja oparta na połaczonych danych FTP-75 i NEDC a aproksymacja oparta tylko na pomiarach NEDC i tylko FTP-75 dla emisji drogowej węglowodorów przy zasilaniu benzyna

Zasilanie benzyną - III stopieñ

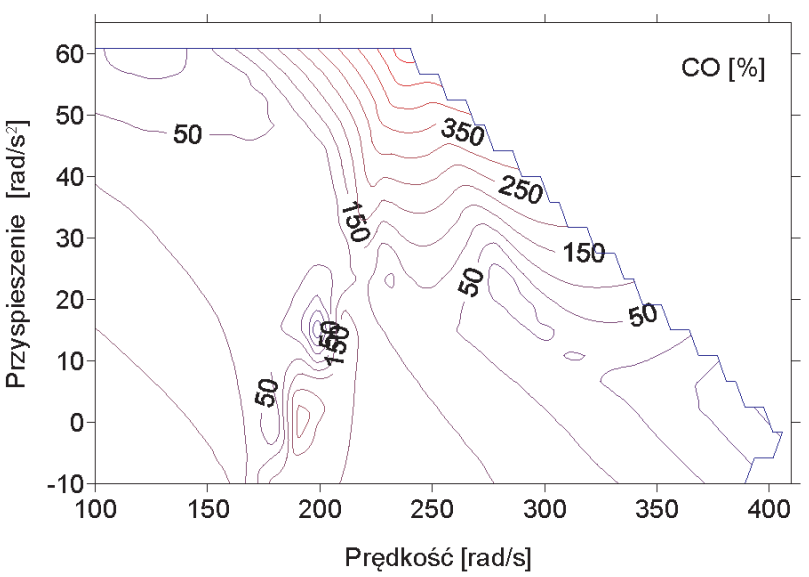

Zasilanie benzyną - III stopieñ

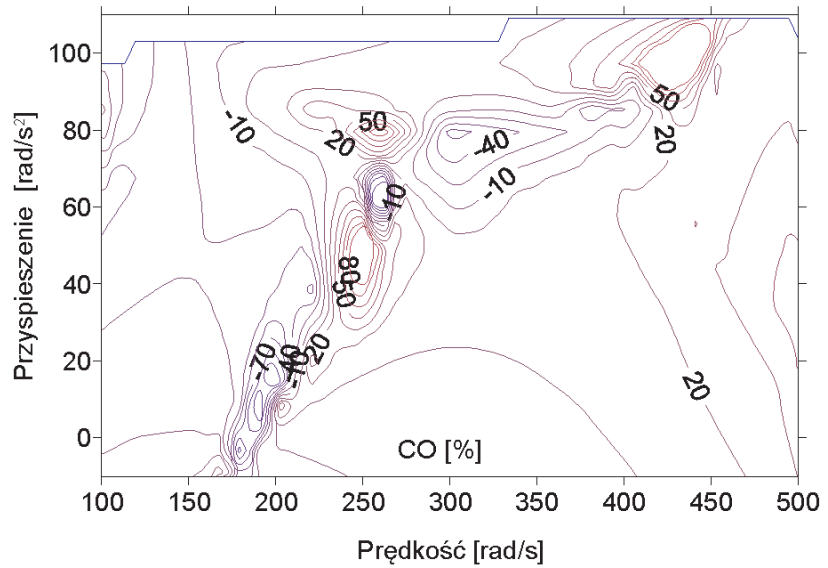

Fig. 8. Errors between the approximation based on the combined data from the FTP-75 and the NEDC and the approximation based on measurements of only the NEDC and only the FTP-75 for the road emissions of carbon monoxide for gasoline fuelling

Rys. 8. Błędy między aproksymacją oparta na połaczonych danych FTP-75 i NEDC a aproksymacja oparta tylko na pomiaryach NEDC i tylko FTP-75 dla emisji drogowej tlenku węgla przy zasilaniu benzyna

FTP-75 tests. Hence, this characteristics lies entirely below the reference characteristics. The approximation of the emission based on the data from the FTP-75 test has errors of positive value (lies above the reference characteristics), and the level of the errors is much lower than in the case of the characteristics based on the data from the NEDC tests. The greatest error values occur at high accelerations and high engine speeds, thus in a range that practically does not occur in regular vehicle operation.

The maps of the on-road emission of carbon monoxide obtained based on individual tests and presented in the form of multinomials of the third order locally diverge from the values in the maps built based on the combined NEDC and FTP-75 driving tests. When analyzing these maps we can see that the mapping errors obtained in the FTP-75 test have values of one order of magnitude lower than the errors ob- rzystaniu danych z pojedynczych testów. Różnice zaprezentowano na rys. 7-10.

Oceniając powyższe wykresy, warto zwrócić uwagę, że błędy aproksymacji opartej na wynikach z testu NEDC są znaczące i mają wartości ujemne w stosunku do błędów aproksymacji opartej na połączonych danych z testów NEDC i FTP-75. Tak więc charakterystyka ta leży w całości poniżej charakterystyki odniesienia. Aproksymacja emisji oparta na danych z testu FTP-75 zawiera błędy o wartościach dodatnich (leży nad charakterystyką odniesienia), a poziom tych błędów jest znacznie niższy niż przy charakterystyce opartej na danych z testu NEDC. Największe wartości błędów występują przy dużych przyspieszeniach i dużych prędkościach obrotowych, a więc w obszarze praktycznie niewystępującym w eksploatacji pojazdów. 
tained based on the NEDC test. The greatest errors occur at the engine speeds of maximum engine torque.

Analyzing the error maps of the on-road emission of carbon dioxide we can see that lower values occur for the map based on the data from the FTP-75 test. Excluding the values of the errors at deceleration we can see that these errors are within the range of $10 \%$ and their smallest values occur in the range that is most frequently used in vehicle operation. The mapping errors of the on-road emission of carbon dioxide based on the data from the NEDC test are one order of magnitude greater than those obtained in the approximation based on the data from the FTP-75 test.

\section{Conclusions}

Dynamic characteristics of the exhaust emissions under transient states can be a useful tool in the analysis of
Mapy emisji drogowej tlenku węgla uzyskane na bazie pojedynczych testów i przedstawione w postaci wielomianów trzeciego stopnia lokalnie znaczace odbiegają od wartości $\mathrm{z}$ map budowanych na bazie połączonych testów jezdnych NEDC i FTP-75. Analizując te mapy, można stwierdzić, że błędy odwzorowań uzyskane na bazie testu FTP-75 mają wartości o rząd mniejsze od wartości błędów charakterystyki uzyskanej na bazie testu NEDC. Największe wartości błędów występują przy prędkościach obrotowych zbliżonych do prędkości maksymalnego momentu obrotowego silnika.

Analizując mapy błędów emisji drogowej dwutlenku węgla, można zauważyć, że mniejsze wartości występują dla mapy opartej na danych z testu FTP-75. Pomijając wartości błędów przy przyspieszeniach ujemnych, można stwierdzić, że błędy te mieszczą się w granicach $10 \%$, a najmniejsze ich wartości występują w obszarze najczęściej wykorzy-
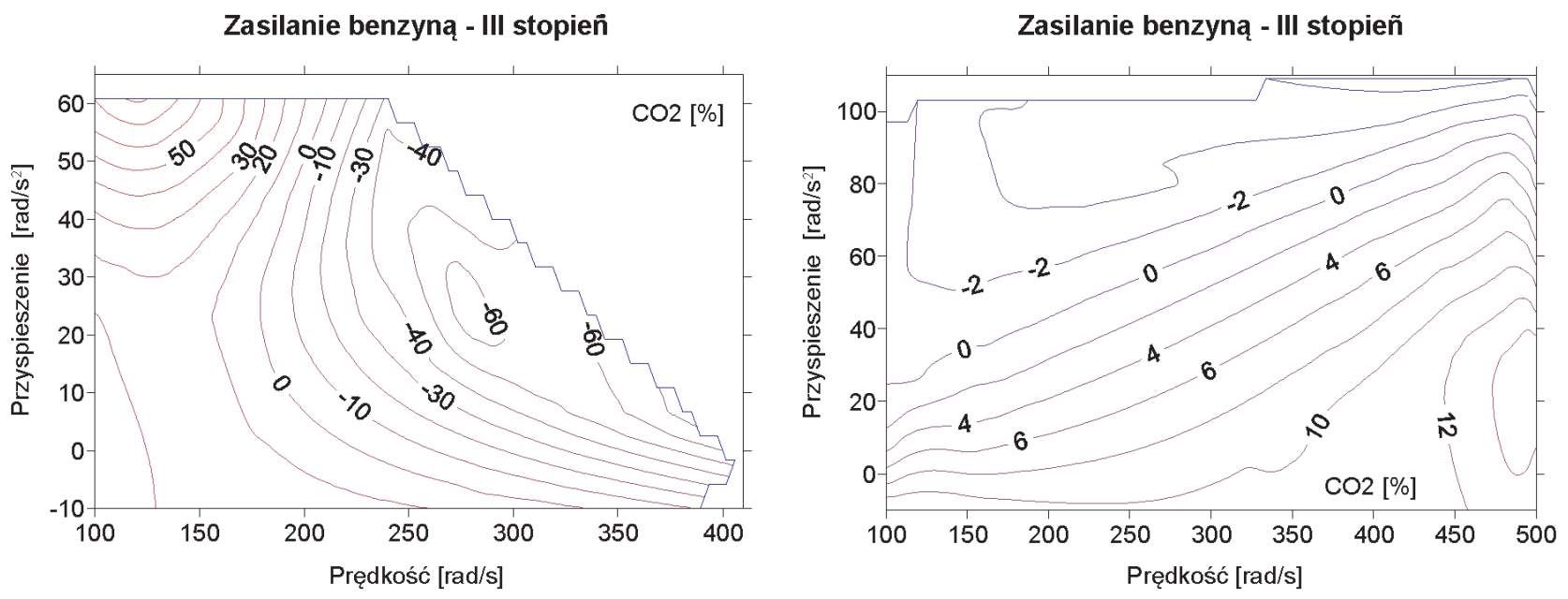

Fig. 9. Errors between the approximation based on the combined data from the FTP-75 and the NEDC and the approximation based on the measurements of only the NEDC and only the FTP-75 for the road emissions of carbon dioxide for gasoline fueling

Rys. 9. Błędy między aproksymacją oparta na połaczonych danych FTP-75 i NEDC a aproksymacja oparta tylko na pomiarach NEDC i tylko FTP-75 dla emisji drogowej dwutlenku węgla przy zasilaniu benzyna

Zasilanie benzyną - III stopieñ

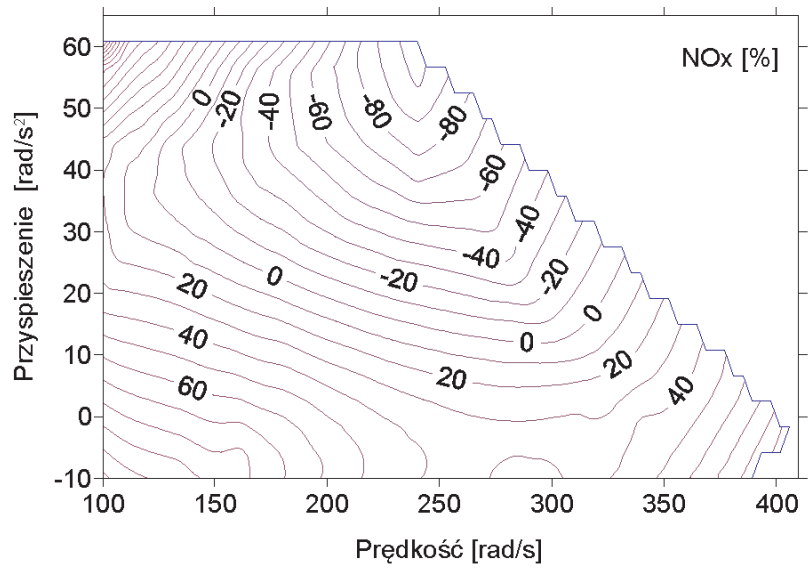

Zasilanie benzyną - III stopieñ

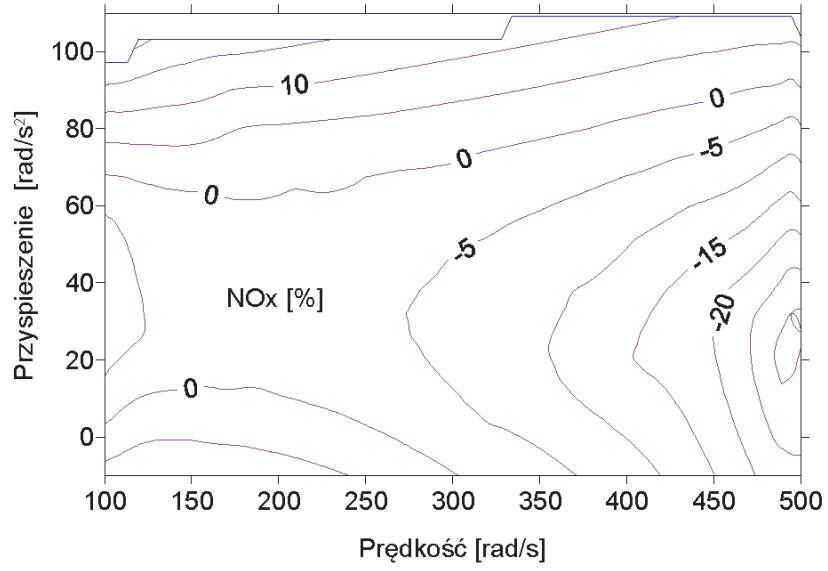

Fig. 10. Errors between the approximation based on combined data from the FTP-75 and the NEDC and the approximation based on measurements of only the NEDC and only FTP-75 for the road emissions of nitrogen oxides for gasoline fuelling

Rys. 10. Błędy między aproksymacja oparta na połaczonych danych FTP-75 i NEDC a aproksymacja oparta tylko na pomiarach NEDC $i$ tylko FTP-75 dla emisji drogowej tlenków azotu przy zasilaniu benzyna 
vehicles in motion that are treated as a source of pollution. Yet, we need to be aware of the errors that occur at various algorithms of the formation of these characteristics. In the authors' opinion, satisfactory results can be achieved if for the approximation the combined data from the NEDC and FTP-75 are used. For the researchers an important temptation may be the drive to create such characteristics based on one of the tests exclusively. This paper indicates possible errors that arise from that. The performed analyses allow some generalizations set forth below:

- Dynamic characteristics of the exhaust emission components based on the data from the FTP-75 test are burdened with fewer errors as compared to the values obtained from the approximation based on the combined data from the NEDC and FTP-75 tests. One of the justifications of the above could be the fact that for the combined data from both tests a higher number of measuring points is contributed by the FTP-75 test and it is a test of lower acceleration amplitudes.

- The worst mapped characteristics are of the on-road emission of carbon monoxide. An explanation of this state could be the programmed fuel injection control characteristics that, for high instantaneous accelerations stimulate the feed of rich air-fuel mixture.

- The occurrence of the emission at decelerations does not exclusively result from the approximation methods. The results of the investigations of this engine operating range were discussed in [9].

\section{Paper reviewed}

\section{Bibliography/Literatura}

[1] Romaniszyn K.M.: Ocena różnic w określaniu zużycia paliwa samochodu na podstawie charakterystyki uniwersalnej i dynamicznej. Silniki Spalinowe 2/2004 (119).

[2] Romaniszyn K.M.: Alternatywne zasilanie samochodów benzyną oraz gazami LPG i CNG - badania porównawcze dynamiki rozpędzania oraz emisji spalin. WNT, Warszawa 2007.

[3] Bielaczyc P., Merkisz J., Pielecha J.: Stan cieplny silnika spalinowego a emisja związków szkodliwych. Press of TU, Poznań 2001.

[4] Brzozowski K., Romaniszyn K.M.: An effective method of creating dynamic characteristics using drive tests. The Archive of Mechanical Engineering, 4/2003, Vol. L.

[5] Chłopek Z.: Modelowanie procesów emisji spalin w warunkach eksploatacji trakcyjnej. Scientific Papers in Mechanics 175, Press of TU, Warsaw 1999.

Kazimierz M. Romaniszyn, DSc., DEng. - Professor in the Faculty of Mechanical Engineering and Computer Science at University of Bielsko-Biala. Prof. dr hab. inż. Kazimierz M. Romaniszyn-profesor na Wydziale Budowy Maszyn i Informatyki Akademii Techniczno-Humanistycznej w BielskuBialej.

e-mail: kromaniszyn@ath.bielsko.pl

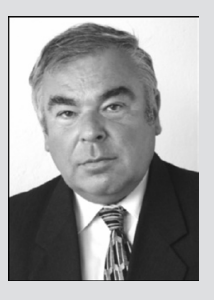

stywanym w eksploatacji samochodów. Błędy odwzorowań emisji drogowej dwutlenku węgla w oparte na danych z testu NEDC są o rząd wielkości większe od wartości uzyskanych w aproksymacji opartej na danych z testu FTP-75.

\section{Podsumowanie}

Charakterystyki dynamiczne emisji składników spalin w warunkach dynamicznych mogą być przydatnym narzędziem w analizach ruchu pojazdów traktowanych jako źródło zanieczyszczeń. Jednak należy zdawać sobie sprawę z błędów powstających przy różnych algorytmach tworzenia takich charakterystyk. Zdaniem autorów tego artykułu, zadowalające wyniki daje wykorzystanie do aproksymacji połączonych danych z testów NEDC i FTP-75. Dla badaczy istotną pokusą może być chęć tworzenia takich charakterystyk, opierając się na danych tylko jednego z tych testów. Niniejsza publikacja podaje możliwe błędy z tego wynikające. Przeprowadzone analizy pozwalają na poniższe uogólnienia:

- Charakterystyki dynamiczne emisji składników spalin oparte na danych z testu FTP-75 są obarczone mniejszymi błędami względem wartości uzyskanych z aproksymacji opartej na połączonych danych testów NEDC i FTP-75. Jednym z uzasadnień tego może być fakt, że do połączonych danych $\mathrm{z}$ obydwu testów większą liczbę punktów pomiarowych wnosi test FTP-75 i jest testem o mniejszych amplitudach przyspieszeń.

- Najgorzej odwzorowywane są charakterystyki emisji drogowej tlenku węgla. Wytłumaczeniem tego stanu mogą być zaprogramowane charakterystyki sterowania wtryskiem paliwa, które dla dużych chwilowych przyspieszeń stymulują podawanie bogatej mieszanki benzyna-powietrze.

- Występowanie emisji przy ujemnych przyspieszeniach nie wynika wyłącznie z metod aproksymacyjnych. Wyniki badań dotyczące tego zakresu pracy silnika ujęto w [9].

[6] Brzozowski K., Romaniszyn K.M.: Wyznaczanie charakterystyk dynamicznych zużycia paliwa i emisji związków szkodliwych spalin w oparciu o badania na hamowni podwoziowej. Materiały Ogólnopolskiej Konferencji „Pojazd a środowisko”, Radom 2003.

[7] Romaniszyn K.M., Wojciech S.: Influence of fuel on economical and ecological car acceleration. The Archive of Mechanical Engineering, Vol. LI, 1/2004, p. 32-48.

[8] Merkisz J., Pielecha J., Radzimirski S.: Pragmatyczne podstawy ochrony powietrza atmosferycznego w transporcie drogowym. Wydawnictwo Politechniki Poznańskiej, Poznań 2009.

[9] Romaniszyn K.M.: The use of piston engine brake as related to the emission of selected exhaust gas components. Combustion Engines 1/2008 (132).

Henryk Wnęk, PhD., DEng. - doctor in the Faculty of Mechanical Engineering and Computer Science at University of Bielsko-Biala.

Dr inż. Henryk Wnęk-adiunkt na Wydziale Budowy Maszyn i Informatyki Akademii Techniczno-Humanistycznej w Bielsku-Biatej.

e-mail:hwnek@ath.bielsko.pl

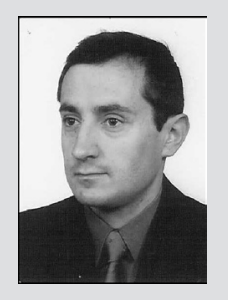

